\title{
International criteria for assessment of accreditation of educational activities
}

\author{
Nadezhda Efremova ${ }^{1, *}$, Timur Tabishev ${ }^{2}$ \\ ${ }^{1}$ The Don State Technical University, 1, pl. Gagarina, 344000, Rostov-on-Don, Russia \\ ${ }^{2}$ The Kabardino-Balkarian State University them. H.M. Berbekova, 173, st. Chernyshevsky, 360004 , \\ Nalchik, Russia
}

\begin{abstract}
The article gives a comparative and analytical review of the national systems of accreditation of educational programs according to European, Asia-Pacific and Russian standards of quality assurance in higher education. The emphasis is on the structuring of the main provisions and features of foreign and domestic accreditation systems in the field of education. The main universal blocks of educational activity assessed at accreditation are identified: management of educational process, resources and provision of educational activity, competence and qualification model of a graduate. In accordance with the principles of international and national standards, the requirements to the accreditation procedures of educational activity are set out in the main (universal) diagnostic blocks. For the evaluation of educational activity during the accreditation of higher education institutions the criteria of achievements are given. It is noted that the most important criterion of quality of education at accreditation is the evaluation of educational achievements of students. Difficulties of evaluation of educational results and ensuring their comparability at the international level for understanding the quality of training of specialists in different educational systems are noted. The lack of reliable evaluation tools creates certain difficulties in accreditation. The most problematic is the development and application of evaluation materials with planned activities to identify the levels of competence of students and graduates.
\end{abstract}

\section{Introduction}

The current decade is characterized by joining efforts of a number of European countries to develop common conceptual approaches to ensure, guarantee and evaluate the quality of education. Ministerial Conferences in Yerevan (2015) and Paris (2018) note in their declarations that the countries participating in the Bologna Process intend to come to the Common Space of Higher Education (EHEA). The goal is to achieve common goals of mutual trust to higher education systems for automatic recognition of qualifications. The

\footnotetext{
* Corresponding author: nefremova61@donstu.ru
} 
basis of the EHEA is a common structure of education levels and credit system, common quality standards and norms, cooperation and mobility, joint programs and degrees. In the conditions of fierce competition of HEIs it becomes more and more important for professional education to create and operate reliable systems of provision, guarantee and evaluation of educational results first of all in order to understand what to do next in the educational process. Much attention is paid to the need to develop at the international level comparable criteria and a common methodology to assess the quality of education.

The purpose of this research is to show the features of foreign and domestic systems of accreditation of educational activities, identifying common points and nuances of differences. We will focus on the characteristics of three universal models of education quality assurance and guarantee: European - European Standards and Guidelines, European Network for Quality Assurance (ESG) [1-3]; Asia-Pacific - The «Chiba Principles», Higher Education Quality Assurance Principles for the Asia-Pacific Region (CHIBA) [4, 5]; Russian - National Accreditation Agency (NAA, Rosakkredagency) [6] based on the requirements of federal state educational standards of higher education (FSES HE).

\section{Materials and methods}

Mechanisms of evaluation and quality assurance of education (or individual elements) largely depend on the characteristics of national education systems, the uniqueness of which is undoubted, which ensures their originality and diversity [7]. Centuries-old traditions in these systems and individual legislative foundations of the regulation of educational activities should certainly be preserved, ensuring the national color of education. However, it should be noted that the processes of globalization and internationalization have had the strongest impact on national education systems, ensuring their convergence. This is quite natural, given the increasing role of international academic mobility of students and research and teaching staff, the significant increase in international cooperation and the priority importance of exporting educational services, including those of the Russian Federation. In these conditions, the systems of ensuring and guaranteeing the quality of education have been somewhat transformed, making the aspect of a harmonious convergence of criteria for accreditation and ensuring the reliability of evaluation procedures. Regardless of the scale of their influence in the world, national affiliation and regulatory and legal regulation in the field of education, all accreditation systems use the basic blocks of requirements and guarantees of education quality, ensuring the reliability of evaluation of educational achievements of graduates.

In the European Association for Quality Assurance in Higher Education (ENQA) model, key blocks of quality indicators can be identified. These include: the quality of educational programs; the quality of teaching staff; research and innovation activities of the university; the state of the material and technical base of the educational institution; the quality of students; the quality of student learning outcomes; the demand of graduates in the labor market and the achievements of graduates in the production sphere [8]. A special form of formal decision making and approval by the legal body of the institution or program, the quality of which meets the pre-established agreed standards, are the goals and objectives of accreditation. The main thing in the evaluation of the efficiency of educational activity is not the planning and organization of the educational process (content of curricula, teaching time, etc.), including independent learning and self-education, but the 
results of education: knowledge and skills of students and graduates, and the main levels of competence formation.

The key objective of the ESG is to promote in all EHEA countries a common understanding of quality assurance among all stakeholders and to develop national and institutional quality assurance systems. Following common standards ensures transparency and mutual trust, recognition of qualifications, educational programs and other types of educational process implementation. ESG requirements do not apply to partner organizations in other regions of the world.

A feature of CHIBA is the development of quality assurance principles for higher education to strengthen cooperation in quality assurance in the Asia-Pacific region. These include: regional harmonization in quality assurance issues and methods; comparative analysis in quality assurance and quality assurance; student and academic mobility and mutual trust; mutual understanding of higher education systems in the Asia-Pacific region and their correspondence to international quality assurance achievements.

The activity of NAA, as a national system, is to carry out the function of organizational, technical and information-analytical support of the procedures of state accreditation of educational organizations within the powers of the Federal Service for Supervision in Education and Science (Rosobrnadzor) in accordance with the principles of objectivity, responsibility, openness, independence and transparency, ensuring external quality assessment of Russian education. Educational organizations that have state accreditation have been confirmed to provide a guarantee of compliance with the requirements of the Federal Service for Supervision of Education and Science (Rosobrnadzor) and the main educational programs of higher education. The procedure of accreditation expertise is conducted in order to obtain an expert assessment of the completeness of their composition and quality to assess the achievement of students' planned results of the educational program in a separate part or the entire volume of the subject, course, discipline (module), as well as the degree and level of students' mastery of the educational program. One of the moments of examination is the determination of quality of the evaluation materials used by the educational organization for compliance with the authentic assessment of students' achievements.

If we consider and compare these «regulators» of educational activities in terms of responsibility for the quality of the education system as a whole, each of the accreditation models has its own features, but there are also common features. The European and AsiaPacific models are more focused on accreditation independent of the state and federal authorities. Such accreditation agencies may receive government grants and participate in federal national programs and projects, but they are not federally subordinate organizations. The main and main difference between the Russian educational system and the educational systems of the absolute majority of countries in the European and Asia-Pacific regions is the responsibility of the state (the state body of legislative and executive power) for the proper quality assurance of education and training of students, accreditation of educational activities. Nevertheless, the Russian legislation in the sphere of education allows not only the state participation in the evaluation of the educational process, but also the activity of other stakeholders (both Russian and foreign). Federal Law «On Education in the Russian Federation» [9] implies taking into account the opinions of all interested parties, as well as the functioning of organizations that provide services for an independent assessment of the quality of education, public and professional public (international) accreditation of major professional educational programs based on professional standards and qualification guides, international standards and recommendations (ESG, CHIBA, FSES HE etc.). Permissive 
legislation allows the Russian accreditation system to define goals, set specific objectives and participate in the formation of the qualification and competence model of future specialists, taking into account international experience. Like the two above, it is focused on the universal assessment blocks of accreditation, declared at the international level.

\section{Results}

Comparative and analytical review of the accreditation expertise of higher education programs by ESG, CHIBA and NAA methods showed that we can distinguish three macroblock requirements for the accreditation expertise of educational activities (EA) of educational organizations (EOs): management system, resources and provision, competence and qualification model of a graduate (Table 1).

Table 1. Universal evaluation blocks.

\begin{tabular}{|l|l|l|}
\hline Control System & Resources and provisioning & \multicolumn{1}{|c|}{$\begin{array}{c}\text { Graduate competence- } \\
\text { qualification model }\end{array}$} \\
\hline $\begin{array}{l}\text { mission, quality policy, } \\
\text { structure, } \begin{array}{r}\text { strategic } \\
\text { guidelines, external } \\
\text { relations, etc. }\end{array}\end{array}$ & $\begin{array}{l}\text { personnel, material and } \\
\text { technical base, teaching and } \\
\text { information resources, etc. }\end{array}$ & $\begin{array}{l}\text { competencies, qualifications, } \\
\text { fields and types of professional } \\
\text { activities, etc. }\end{array}$ \\
\hline
\end{tabular}

Let's consider each universal block in the context of selected accreditation systems on the set of evaluated elements (documents, processes, technologies, etc.) (Table 2).

Table 2. Comparative analysis of the universal units being evaluated when accrediting educational activities.

\begin{tabular}{|c|c|c|c|}
\hline Criterion / indicator & ESG & CHIBA & NAA \\
\hline \multicolumn{4}{|c|}{$\begin{array}{l}\text { MANAGEMENT SYSTEM OF EDUCATIONAL ACTIVITY OF THE EDUCATIONAL } \\
\text { ORGANIZATION OF HIGHER EDUCATION }\end{array}$} \\
\hline Mission and development strategy & + & + & $-*$ \\
\hline $\begin{array}{l}\text { Quality Policy and Functioning of the Quality } \\
\text { Management System }\end{array}$ & + & + & + \\
\hline $\begin{array}{l}\text { Structure (administration, student support services, } \\
\text { training units) }\end{array}$ & + & + & + \\
\hline $\begin{array}{l}\text { Involving external stakeholders in the educational } \\
\text { process }\end{array}$ & + & + & + \\
\hline Public awareness, information transparency & + & + & + \\
\hline \multicolumn{4}{|c|}{$\begin{array}{l}\text { RESOURCES AND PROVISION OF EDUCATIONAL ACTIVITIES OF THE } \\
\text { EDUCATIONAL ORGANIZATION OF HIGHER EDUCATION }\end{array}$} \\
\hline Staff capacity & + & + & + \\
\hline Material and technical base & + & + & + \\
\hline Training and methodological support & + & + & + \\
\hline $\begin{array}{l}\text { Information and communication, electronic and library } \\
\text { resources }\end{array}$ & + & + & + \\
\hline \multicolumn{4}{|l|}{ GRADUATE COMPETENCE-QUALIFICATION MODEL } \\
\hline Educational program, curriculum plan & + & + & + \\
\hline Set of competences and work functions & + & + & + \\
\hline Professional standards and qualification characteristics & + & + & + \\
\hline Procedures for evaluating the quality of training of & + & + & + \\
\hline
\end{tabular}




\begin{tabular}{|l|l|l|l|}
\hline trainees & & & \\
\hline $\begin{array}{l}\text { Success, achievements and awards, scientific, creative } \\
\text { and intellectual potential of students }\end{array}$ & + & + & $+1-*$ \\
\hline
\end{tabular}

Indicator $\left(^{*}\right)$ is an evaluation element for public accreditation of EOs, professional public and/or international accreditation of EA, which are also important links in the Russian accreditation system. Direct assessment of this indicator is included in the procedures of "non-state" regulation of educational activities in the Russian Federation. There are also state procedures of regulation of educational activity that assess this indicator in accordance with the current legislation and the regulatory field of education state control (supervision) in the field of education. The compliance of educational programs with the criteria of national and international professional standards should promote the continuous improvement of educational activity and quality of training of students $[10,11,12]$.

If for the first two blocks it is intuitive and technologically clear how to evaluate and what evaluation mechanisms to apply, in the third block the mentioned accreditation systems have different approaches to the evaluation of the quality of students' training. At present, there are no comparable data in this part. Each system has its own approaches, pedagogical tools, criteria and assessment scales.

The scientifically grounded criteria provide a unified approach to public and professional public accreditation of educational programs of different levels. This creates conditions for consistency and continuity of educational programs, creating in Russia a single space of education that corresponds to international practice (Table 3). At the same time, the process of education becomes more transparent, active and effective when there is consistency between the results of education, learning strategy, learning activities and assessment procedures. This is a very complex task, but only reliable feedback can ensure quality education.

Table 3. Basic quality criteria of education, educational activities and educational programs.

\begin{tabular}{|l|l|l|l|}
\hline № & \multicolumn{1}{|c|}{ Criterion } & \multicolumn{1}{|c|}{ Content } & \multicolumn{1}{|c|}{ Results } \\
\hline 1. & $\begin{array}{l}\text { Program goals and } \\
\text { learning outcomes }\end{array}$ & $\begin{array}{l}\text { compliance with FSES } \\
\text { requirements, requests from } \\
\text { employers and other interested } \\
\text { parties }\end{array}$ & upcoming graduates \\
\hline 2. & Program Content & at least 240 ECTS credits & in credits \\
\hline 3. & $\begin{array}{l}\text { Training process } \\
\text { organization }\end{array}$ & $\begin{array}{l}\text { should ensure that all students } \\
\text { achieve learning outcomes }\end{array}$ & $\begin{array}{l}\text { assessment of students' } \\
\text { achievement of learning } \\
\text { outcomes }\end{array}$ \\
\hline 4. & Teaching staff & $\begin{array}{l}\text { is represented by specialists in all } \\
\text { fields of knowledge covered by the } \\
\text { educational program }\end{array}$ & $\begin{array}{l}\text { active participation in the } \\
\text { implementation of training } \\
\text { and educational, research, } \\
\text { design and scientific and } \\
\text { methodological work }\end{array}$ \\
\hline 5. & $\begin{array}{l}\text { Preparation for } \\
\text { professional } \\
\text { activity }\end{array}$ & $\begin{array}{l}\text { universal, professional competence } \\
\text { and personal qualities }\end{array}$ & $\begin{array}{l}\text { learning outcomes for the } \\
\text { program as a whole and for } \\
\text { individual disciplines } \\
\text { (modules), documents } \\
\text { confirming achievements }\end{array}$ \\
\hline 6. & $\begin{array}{l}\text { Program resources } \\
\text { and student }\end{array}$ & $\begin{array}{l}\text { material, informational and } \\
\text { financial support of the educational }\end{array}$ & $\begin{array}{l}\text { availability of the university } \\
\text { educational environment, }\end{array}$ \\
\hline
\end{tabular}




\begin{tabular}{|c|l|l|l|}
\hline & support system & $\begin{array}{l}\text { program should be not lower than } \\
\text { the license indicators and } \\
\text { correspond to the objectives of the } \\
\text { educational program }\end{array}$ & $\begin{array}{l}\text { organization of a modern } \\
\text { quality management system }\end{array}$ \\
\hline 7. & $\begin{array}{l}\text { Quality of the } \\
\text { system } \\
\text { evaluating } \\
\text { students' } \\
\text { achievements }\end{array}$ & $\begin{array}{l}\text { personnel, technical, technological, } \\
\text { software and tools and } \\
\text { instructional and regulatory } \\
\text { support }\end{array}$ & $\begin{array}{l}\text { evaluation materials, reports, } \\
\text { protocols of results, statistical } \\
\text { analysis of achievements }\end{array}$ \\
\hline 8. & Graduates & job market relevance & graduate employment data \\
\hline
\end{tabular}

It is p. 7 of Table 3 that causes the most serious difficulties in assessing learning outcomes. In the competence and qualification model of vocational education graduates, taking into account the requirements of employers and changes in professional activity in an integrated and integrated form, universal and professional competencies should be formed. The professional qualification determined by the system of knowledge and skills of a graduate, his competence and skills of the XXI century (creativity, critical approach to information, communicativeness and collegiality, etc.), as well as the basic characteristics of the individual (activity, independence, leadership, beliefs, self-esteem, responsibility, etc.) should be evaluated. Thus, the Competency and Qualification Model should be the formalization of what should be learned in training and evaluated when demonstrating the activity of a student and a graduate in a situation of evaluation.

\section{Discussion}

Estimation of the level of competence formation is traditionally a special challenge all over the world [13]. Today, both international and national educational practice lacks unified tools for assessment of competencies, qualifications and skills. As a rule, task banks are created to assess cognitive learning outcomes; most often they are formed spontaneously, their development is not based on the theory and practice of pedagogical measurements, they are not tested and parameterized, and tasks have no statistically substantiated characteristics. But the situation with evaluation of levels of competence formation is even more complicated; their activity nature and specific conditions and requirements necessary for evaluation are not taken into account when assessing them. Most often it is the results of knowledge evaluation that are passed off as competence evaluations, which, in fact, is wrong. However, it should be noted that the demand for competence assessment tools is very high both on the part of higher education organizations and employers (professional communities). Of course, the technology and procedures for assessing students' learning outcomes are changing; the emphasis is on competencies as a single language for describing the results of educational programs. The design of assessment tools by competence differs significantly from the tools for assessing cognitive learning outcomes. In international educational practice, approaches related to the provision of planned activities in tasks are widely used, the implementation of which is accompanied by arguments and evidence of observed manifestations of competencies with the display of results of multi-stage assessment procedures on the level scales [14-17].

\section{Conclusions}


In general, we can consider that the methodology of competency-based learning is still in its infancy. And, accordingly, the accreditation criteria in this part have not been properly developed yet, but are waiting for their approval. The task is actually set in two directions: first, to evaluate students in the transition to the next level of education (for example, from bachelor to master); second, to evaluate graduates and educational organizations in terms of identifying the quality of educational services and their compliance with the requirements of employers and other stakeholders. All this expands the need for modern, reliable assessment tools and quality characteristics. Depending on the purpose of assessment tools may have different content, structural and organizational features. But they should give authentic estimations, to which will be trust of all participants of educational relations.

Naturally, the criterion bases of the considered accreditation systems are not limited to the above mentioned universal blocks. Only those assessment points are reflected here, which allow creating a certain unified educational space practically all over the world. Of course, the national systems of accreditation possess a number of other criteria and indicators of evaluation of the quality of the educational process, but they do not contradict the above mentioned blocks, on the contrary, they complement and strengthen their unique and individual essence. It should be noted that the content of the ESG international standards, CHIBA principles and federal state educational standards of the FSES HE was formed in such a way that it would be able to cover the largest number of evaluation and examination objects during the accreditation process.

\section{References}

1. Official site ENQA, https://enqa.eu/

2. Standards and Guidelines for Quality Assurance in The European Higher Education Area, https://enqa.eu/index.php/home/esg/

3. The European Quality Assurance Register for Higher Education, https://www.eqar.eu/

4. The European Higher Education Area in 2018: Bologna Process Implementation Report, https://eacea.ec.europa.eu/national-policies/eurydice/content/european-highereducation-area-2018-bologna-process-implementation-report_en

5. The Chiba Principles, Higher Education Quality Assurance Principles for the AsiaPacific Region, https://www.apqn.org/media/library/publications/higher_education quality_assurance_principles_for_the_asia_pacific_region_chiba_principles.pdf

6. Asia-Pacific Quality Register (APQR), https://www.apqr.co/ last accessed 2020/08/30

7. Official site of Rosakkredagency, http://www.nica.ru/

8. T.A. Tabishev, SHS Web Conf. 70, 04005 https://doi.org/10.1051/shsconf/20197004005

9. Federal Law «On Education in the Russian Federation», http://www.consultant.ru/document/cons_doc_LAW_140174/

10. N.F. Efremova, B.Ch. Meskhi, S.V. Shvedova, Journal of supranational policies of education 10, 40-56 (2019) DOI: https://doi.org/10.15366/jospoe2019.10.003.

11. J. Knight, International higher education 69, 4-5 (2012) DOI: https://doi.org/10.6017/ihe.2012.69.8644.

12. J. Knight, International Education Hubs: Student, Talent, Knowledge Models (Springer Publishers, Dordrecht, Netherlands, 2014) 
13. R.E. Bennett, Educational Measurement: Issues and Practice 37(4), 7-15 (2018) DOI:10.1111/EMIP.12231

14. P. Griffin, B. McGaw, E. Care, Editors Assessment and Teaching of 21st Century Skills (Springer Dordrecht Heidelberg, London New York, 2012) DOI 10.1007/978-94-0072324-5

15. A.A. Rupp, M. Gushta, R.J. Mislevy, D.W. Shaffer, Journal of Technology, Learning, and Assessment 8(4) (2010) http://www.jtla.org last accessed 2020/08/30

16. R.G. Almond, V.J. Shute, International Journal of Testing, 1-22 (2016) DOI:10.1080/15305058.2015.1108322

17. N.F. Efremova, EC Psychology and Psychiatry SI.02, 01-04 (2020) 